УДК 502.131.1

\title{
Н.В. Помазкова
}

\section{СОЗДАНИЕ УЧЕБНО-НАУЧНОГО СТАЦИОНАРА «КУЛИНДА» И ПЕРСПЕКТИВЫ ВОВЛЕЧЕНИЯ РЕГИОНАЛЬНОЙ ООПТ В СОЦИАЛЬНО-ЭКОНОМИЧЕСКОЕ РАЗВИТИЕ РАЙОНА}

Основным принципом зеленой экономики является организация её таким образом, чтобы повышать благосостояние людей, обеспечивать социальную справедливость и при этом существенно снижать экологические риски. Целью статьи выступает исследование возможностей и условий вовлечения создаваемой региональной охраняемой территории в социально-экономическое развитие. Учебно-научный стационар (УНС) «Кулинда» в Чернышевском районе Забайкальского края создается для сохранения и изучения уникального местонахождения ископаемых остатков (фоссилий) динозавра Кулиндадромеуса забайкальского (Kulindadromeus zabaikalicus) и относится к новой категории региональных ООПТ. Проведенные исследования подтвердили природоохранную ценность территории и необходимость создания ООПТ в Чернышевском районе Забайкальского края. Ближайшее сельское поселение (с. Новоильинск) - территория с неблагополучной социально-экономической ситуацией: с низким уровнем жизни, безработицей, ежегодным оттоком населения. Развитие туризма с использованием природных ресурсов и достопримечательностей УНС рассматривается как возможность вовлечения жителей «угасающих» сел в хозяйственную деятельность. Проанализированы имеющиеся возможности и перспективные направления туризма для данного объекта: геологический (геотуризм), академический (научный), образовательный, сельский (агротуризм) и экологический туризм. Рассмотрены негативные факторы, сдерживающие развитие сельских территорий и УНС: недостаточность финансовых средств, низкая транспортная доступность, неразвитость сервисной инфраструктуры и сезонность деятельности УНС. Делается вывод о том, что для сельских территорий развитие туризма на ООПТ может стать точкой роста экономики за счет развития сопутствующих обслуживающих производств и способствовать росту познавательной активности населения.

Ключевые слова: особо охраняемые территории, учебно-научный стационар, Кулинда, Kulindadromeus zabaikalicus, туризм, благосостояние населения.

DOI: $10.35634 / 2412-9518-2019-29-2-290-299$

Сохранение воспроизводственного потенциала природных комплексов страны - это одно из условий достижения стратегической цели устойчивого развития России. Процессы воспроизводства природного капитала регулируются на региональном уровне [1], а создание особо охраняемых территорий (ООПТ) является одной из очевидных «зеленых альтернатив» интенсивного хозяйственного использования природных геосистем территории. Некоторые ООПТ не только сохраняют природные достопримечательности, но и имеют возможность способствовать устойчивому развитию территорий путем вовлечения местного населения в новые виды деятельности, производство товаров и услуг. Возможности получения дополнительного дохода очень актуальны для большинства сельских территорий не только в России, но и во всем мире. Особенно важно создание новых видов экономической активности в полосе приграничья, способствующие закреплению населения и формированию позитивного имиджа территории, что в свою очередь служит решению геополитических задач. Развитие туризма в настоящее время может способствовать повышению экономического регионального роста при сравнительно незначительных негативных последствиях от этой деятельности.

Целью настоящего исследования выступает анализ возможностей и условий, необходимых для вовлечения проектируемой ООПТ в социально-экономическое развитие сельского района в Забайкальском крае.

\section{Объект и методы исследования}

Для проведения исследования применялись традиционные географические методы: анализ статистических материалов, официальных документов, литературных источников и данных полевых исследований. Проведены экспедиционные исследования территории и опрос (анкетирование) местных жителей. Объектом исследования является территория учебно-научного стационара «Кулинда» (рис. 1).

Согласно «Концепции развития ООПТ регионального значения в Забайкальском крае до 2030 года» [2] в крае планируется создание нового для региона типа ООПТ - учебно-научного стационара. 
Учебно-научный стационар (УНС) - это особо охраняемая территория регионального значения, используемая для долговременных научных исследований и экологического мониторинга природоохранными, научными и образовательными организациями. К созданию в крае рекомендовано несколько учебно-научных стационаров, в том числе УНС «Кулинда» в Чернышевском районе ${ }^{1}$. Первым объектом такой категории был недавно созданный УНС «Менза» в Красночикойском районе ${ }^{2}$ [3]

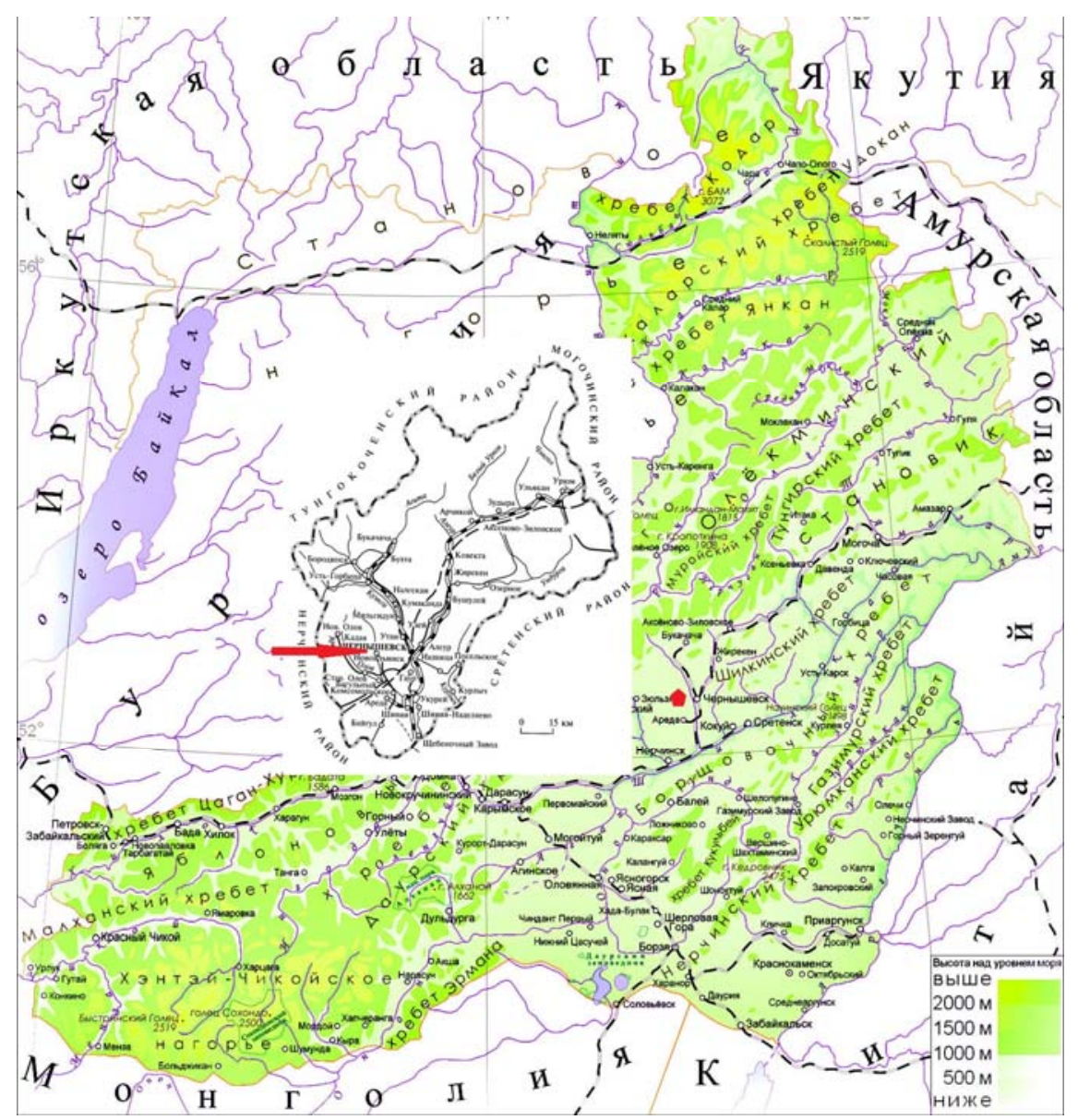

Рис. 1. Карта-схема расположения учебно-научного стационара «Кулинда

По международной классификации Международного союза охраны природы (МСОП) данный вид ООПТ наиболее соответствует категории VI - управляемый ресурсный резерват (щадящее использование экосистем). В данной категории приоритетными видами использования являются: научные исследования, охрана природных и культурных достопримечательностей, экологическое образование, туризм, а также поддержание культурных традиций и обычаев населения [4].

\section{Результаты и их обсуждение}

Общая площадь проектируемого УНС «Кулинда» составляет 86 га, из них земли лесного фонда занимают 49,19 га; остальная часть расположена на землях существовавшего здесь ранее (до 1992 г.) колхоза «Страна Советов». Учебно-научный стационар «Кулинда» создается для сохранения в качестве объекта научных исследований территории, где в 2010 г. в туфоалевролитах были найдены разрозненные отпечатки костных остатков (фоссилий) ${ }^{3}$ юрского динозавра Кулиндадромеуса забайкальского (Kulindadromeus zabaikalicus).

\footnotetext{
1 Закон Забайкальского края от 9 марта 2010 г. № 338-33К «Об особо охраняемых природных территориях в Забайкальском крае».

${ }^{2}$ Постановление Правительства Забайкальского края от 25 сентября 2018 г. № 402.

${ }^{3}$ URL: http://paleontologylib.ru/books/item/f00/s00/z0000035/st005.shtml
} 
Kulindadromeus zabaikalicus - впервые в мире обнаруженный растительноядный ящер с оперением. Ранее считалось, что перьями были покрыты динозавры-хищники из подотряда тероподов. Данная находка, по оценкам научного сообщества, вошла в «Топ-10» самых значимых открытий 2014 г. по версии журнала «Science» [5]. Уникальность проектируемого УНС заключается в том, что на его территории обнаружены фоссилии костного материала растительноядного динозавра кулиндадромеуса: фрагменты бугристой кожи, разнообразное (в том числе с микрочешуйками) оперение и чешуйчатые покрытия хвостов [6-9]. Местонахождение ископаемых остатков динозавра «Кулинда» перспективно для дальнейшего поиска самых разнообразных представителей животного мира юрского периода - на территории представлены палеонтологические обнажения, из которых отобраны эталонные образцы редких окаменелостей хорошей сохранности. Как в России, так и во всём мире подобные местонахождения пока не известны, поэтому УНС «Кулинда» может стать объектом научного туризма мирового уровня.

Уникальность палеонтологического объекта несет в себе и потенциальные угрозы для его сохранности, в том числе и угрозу разграбления с целью нелегальной добычи образцов для продажи на «черном рынке» в частные коллекции. В связи с этим возникает необходимость придания охранного статуса для данной территории, которая реализуется путем включения объекта в сеть ООПТ края и придания ей статуса охраняемой территории регионального значения. С этой целью в 2017 г. были проведены комплексные исследования и подготовлено эколого-экономическое обоснование организации учебно-научного стационара в Чернышевском районе. Исследования подтвердили наличие широкого спектра познавательных объектов на территории стационара и возможность их включения в туристические маршруты, а также высокую природоохранную значимость территории.

Основные охраняемые объекты территории УНС «Кулинда» ${ }^{4}$ :

1. Местонахождение ископаемых остатков динозавра Kulindadromeus zabaikalicus - магистральные геологические канавы №3 и №4 с захоронениями фоссилий динозавров, которые представлены разобщенными отпечатками костей - черепов, челюстей, костей конечностей, позвонков, ребер, когтей, костей тазового и плечевого поясов, коракоидами, фрагментами разнобугорчатой кожи, разнообразным оперением, чешуйчатым покрытием хвостов, гастролитами. Совместно с ними найдены фрагменты панцирей щитней, единичные конхостраки и остракоды, домики ручейников, куколки комаров, надкрылья жуков, следы жизнедеятельности илоедов. Среди растительных фоссилий в породе доминируют талломы печеночных мхов, коробочки сплахновых мхов, более редки стебли хвощей, иглы чекановскиевых, семена-крылатки хвойных. По ископаемым остаткам беспозвоночных организмов и растений относительный возраст определен как позднеюрский (163-145 млн лет назад).

2. Редкие и находящиеся под угрозой исчезновения виды дикорастущих растений, занесенные в Красную книгу Забайкальского края: красоднев малый (Hemerocallis minor Miller), лилия карликовая (Lilium pumilum Delile), ясенец мохнатоплодный (Dictamnus dasycarpus Turcz.), луносемянник даурский (Menispermum dahuricum DC), вздутоплодник сибирский (Phlojodicarpus sibiricus (Fischer ex Sprengel) Koso-Pol.), шлемник байкальский (Scutellaria baicalensis Georgi.), щитовник пахучий (Dryopteris fragrans (L.) Schott), молочай Фишера (Euphorbia fischeriana Steudel.).

3. Редкие и находящиеся под угрозой исчезновения виды птиц: журавль красавка (Anthropoides virgo), большой подорлик (Aquila clanga).

4. Редкие и уникальные сообщества: сообщества нителистниковых (Filifolium sibiricum) степей, характерных для горно-степного пояса с хрящеватыми и каменистыми горными черноземами. Этот тип сообществ является эталоном зональной растительности Даурии, эндемичным растительным сообществом Забайкалья. В составе их ценофлоры отмечено наибольшее число ценных ресурсных растений, редких и охраняемых видов, эндемов и гемиэндемов Восточного Забайкалья. Эти растительные сообщества включены в Зеленую книгу Сибири [10].

Таким образом, кроме собственно участка местонахождения ископаемых остатков динозавра, на остальной территории находятся другие геологические и геоморфологические объекты: магистральные геологические канавы, гранитные останцы, овраги вдоль склона. На участках степной растительности с редкими видами сообществ могут быть организованы пространственно-временные наблюдения за факторами географической среды и функциональными показателями геосистем по методу комплексной ординации [11].

\footnotetext{
${ }^{4}$ Отчет «Эколого-экономическое обоснование создания государственного учебно-научного стационара "Кулинда" в Забайкальском крае». Чита, 2017. 70 с.
} 
В целом данная территория оценивается как перспективная для развития следующих направлений туризма:

- геологический туризм (геотуризм) - посещение в той или иной степени уникальных объектов геологического наследия $(\mathrm{OГН)}$ в целях получения информации относительно внутреннего строения и эволюции Земли [12];

- академический (научный) туризм - это целенаправленное посещение объектов геологического наследия учеными и студентами в целях проведения научно-исследовательской работы [13;14];

- образовательный туризм - проведение на территории стационара полевых практик для студентов географических, геологических, экологических специальностей и летних исследовательских лагерей школьников;

- экологический туризм - посещение относительно незатронутых антропогенным воздействием природных территорий, знакомство с их особенностями без нарушения целостности экосистем для изучения местных видов флоры и фауны, культурных традиций населения;

- сельский туризм (агротуризм) предполагает размещение туристов в ближайшем сельском населенном пункте (с. Новоильинск) с целью посещения достопримечательностей, в том числе местонахождения ископаемых остатков динозавра Кулиндадромеуса забайкальского.

Необходимо отметить, что УНС «Кулинда» можно рассматривать как один из объектов показа в составе комплексного маршрута по археологическим и палеонтологическим памятникам Чернышевского района [15].

Актуальность создания ООПТ продиктована не только значимостью для сохранности уникального палеонтологического объекта, но и тем обстоятельством, что на территории Чернышевского района в настоящее время нет особо охраняемых территорий. Соответственно, в структуре земельного фонда Чернышевского района нет земель охраняемых территорий, поэтому Чернышевский район входит в группу 14 районов Забайкальского края с несбалансированной структурой экологохозяйственного баланса и высокой степенью незащищенности геосистем [16].

Чернышевский район - это обширная территория в центральной части Забайкальского края площадью 13,2 тыс. км², находящаяся на значительном удалении от краевого центра (392 км). В природном отношении территория района представляет собой сочетание таежных, подтаежных, степных и лесостепных ландшафтов.

Численность постоянного населения Чернышевского района составляет 32538 человек (на 01.01.2018 г.); на его территории расположено 18 поселений: четыре городских и 14 сельских. Ближайший к территории проектируемого стационара населенный пункт - с. Новоильинск, расположен в 3-х км от проектируемого стационара и 25 км от районного центра (ст. Чернышевск), численность сельского населения составляет 302 человека. За последние 10 лет в районе наблюдается сокращение численности постоянно проживающего населения, преимущественно за счет миграции. Так, ежегодно число выбывших жителей больше числа прибывших в 1,5-2 раза (в основном это лица трудоспособного возраста). Наибольшая убыль зарегистрирована в поселении Новоильинское (-38 \%).

По данным администрации района, в с. Новоильинск отсутствуют промышленные и сельскохозяйственные предприятия. Ранее территория сельского поселения Новоильинское входила в территорию колхоза «Страна Советов», после реорганизации которого земли сельскохозяйственного назначения были разделены на 342 пая (по 28 га каждый), при этом в поселении на 01.10.2017 г. не было отмежеванных земельных долей.

Денежные доходы занятого населения формируются в основном за счет заработной платы в социальной сфере (образование, государственное управление, медицина, культура). За пределами села трудятся 7 человек (13\% от числа занятых), а в личных подсобных хозяйствах занято 52 человека. Из субъектов хозяйственной деятельности осуществляют свою деятельность один ИП, одно КФХ, СПК «Новый» (занято 7 человек). Официально зарегистрированных безработных - 11 человек5.

Одной из центральных проблем рынка труда является несоответствие спроса и предложения. В сельской местности предложение рабочей силы превышает спрос на постоянных работников. Незанятое население выживает за счет личных подсобных хозяйств, социальных пособий, пенсий и зарплат других членов семьи (в трудоспособном возрасте данная категория населения составляет 68 \% от чис-

\footnotetext{
${ }^{5}$ Отчет «Эколого-экономическое обоснование создания государственного учебно-научного стационара "Кулинда" в Забайкальском крае». Чита, 2017. 70 с.
} 
ленности данной возрастной группы). Доля населения с доходами ниже прожиточного минимума $43,5 \%$.

Таким образом, ближайшее окружение проектируемого УНС - глубоко депрессивная территория с неблагополучной социально-экономической ситуацией, характеризующейся снижением уровня жизни не только в сравнении с краевыми показателями, но и внутри всего Чернышевского района. Отсутствие промышленных предприятий и низкий уровень развития сельскохозяйственного производства в с. Новоильинск являются факторами, способствующими формированию социальной напряженности. Отток населения с целью изменения условий своей жизни к лучшему в другие населенные пункты района и за его пределы (особенно в трудоспособном возрасте) является следствием безработицы и низкой доходности домохозяйств.

В комплексной программе социально-экономического развития муниципального района «Чернышевский район» Забайкальского края на 2011-2020 гг. [17] обозначены следующие приоритетные направления: развитие горнодобывающего производства, агропромышленного комплекса и дорожной инфраструктуры, при этом опорные территории расположены вдоль железнодорожной ветки Забайкальской железной дороги. В программе развития Чернышевского района до 2020 г. такой раздел экономической деятельности, как туризм вовсе не обозначен, в том числе и в разделе развития малого предпринимательства, также отмечается отсутствие экономической перспективы развития части сельских поселений района. Так, в целях оптимизации расходов бюджета муниципального района в программе планируется ликвидировать муниципальные образования: сельские поселения «Гаурское», «Икшицкое», «Курлыченское», «Новоильинское», «Бушулейское», «Новооловское» путем присоединения их к более крупным поселениям.

Основной проблемой, оказывающей негативное влияние на развитие муниципальной экономики, называется недостаточность финансовых средств и осуществление финансирования по остаточному принципу. Это является главным сдерживающим фактором, препятствующим развитию экономики района в целом. Таким образом, сложившаяся социально-экономическая ситуация в сельском поселении остается сложной.

Создание учебно-научного стационара характеризуется отсутствием конфликта интересов со стороны жителей. К настоящему моменту только часть предлагаемой для ООПТ территории используется под пастбища, остальные земли поселения Новоильинское являются частью лесного фонда и относятся к землям, не занятым лесными насаждениями. Территория проектируемого учебно-научного стационара непригодна для использования сельским населением (рубок), на ней нет населенных пунктов, нет традиционных мест отдыха жителей окрестных сел. Использование ресурсов территории населением осуществляется без оформления арендных отношений (или каких-либо других).

Согласно региональному законодательству и Положению о научном стационаре, его финансирование, управление и охрану будет осуществлять региональное Министерство природных ресурсов, в частности его подведомственная организация - КГУ «Дирекция ООПТ Забайкальского края», в оперативном управлении которого находятся все ООПТ регионального значения. Для этих целей будет выделена штатная единица в составе организации - государственный инспектор в области охраны окружающей среды [18]. Обладая административным ресурсом, дирекция ООПТ может взять на себя роль функции планирования, управления и мониторинга деятельности стационара.

Основной вид экономической деятельности проектируемого стационара является оказание услуг, а сферой его деятельности - туризм. Развитие туризма будет способствовать вовлечению населения с. Новоильинск и ближайших населенных пунктов в социально-экономическое развитие района. Формирование потока посетителей в период функционирования стационара отчасти может способствовать развитию предпринимательской активности граждан через их привлечение в обслуживание туристов (проживание, питание, производство сувениров и пр.).

В целом геотуризм находится в ранней стадии коммерческого развития во всем мире, но с каждым годом набирает все большую популярность - формируется отдельный рынок геотуристических услуг [19]. Так, например, Гондурас стал первой страной, которая сделала геотуризм своей национальной туристической стратегией [12].

В мировой практике есть несколько примеров сельских территорий, когда развитие туризма, основанного на палеонтологических находках, стало социально-экономической «точкой роста» [20]. Наиболее близкий по тематике пример - деревня Эль-Кастеллар в провинции Тироль (Испания) с населением 58 человек (по данным переписи 2016 г.), где на основе палеонтологических находок дино- 
завров был создан палеонтологический парк «Динополис» и несколько туристических маршрутов; в результате данное сельское поселение ежегодно посещают сотни туристов [21]. Для самого местонахождения остатков динозавров с помощью привлеченных грантовых средств были проведены важные мероприятия по консервации разрезов и сооружению защитных конструкций для предотвращения повреждения участка от эрозии.

В публикациях, анализирующих экономическую отдачу туристической отрасли, отмечается, что основную часть доходов от развития туризма на охраняемых территориях получают не сами ООПТ, а бизнес, обслуживающий туристов (гостиницы, автозаправочные станции, магазины, туроператоры и пр.). По оценкам зарубежных исследователей, соотношение затрат на содержание ООПТ и доходов, получаемых от экологического туризма, во многих странах составляет 1:5 [22]. Высокий уровень доходности зависит прежде всего от качества предоставляемых услуг, грамотного маркетинга и категорий посетителей (коммерческие и некоммерческие группы).

Негативными факторами, сдерживающими формирование устойчивого туристического спроса, на данной территории являются следующие:

1. Низкая транспортная доступность. Расстояние от пос. Чернышевск до краевого центра г. Чита составляет 392 км по железной дороге и 309 км по автомобильной дороге, но в то же время г. Чита доступен для нескольких видов транспорта (авиационный, железнодорожный), однако он находится в стороне относительно центров, создающих туристические потоки.

2. Неразвитость сервисной и транспортной инфраструктуры. Отсутствие мест проживания и питания в с. Новоильинск, а также временного (летнего) лагеря на территории учебно-научного стационара. Ближайшие гостиницы и места общественного питания находятся только в пос. Чернышевск (35 км от проектируемого учебно-научного стационара).

3. Сезонность деятельности стационара, связанная в первую очередь с климатическими условиями. Проведенный в ходе исследования анализ показал, что использование стационара для полевых практик и исследовательских экспедиций с проживанием в летнем палаточном лагере возможно в период с июня по август, а для экскурсий - с мая по сентябрь. В зимние месяцы низкие среднесуточные температуры воздуха не позволяют проводить длительные экскурсии, а проживание в стационаре в это время невозможно без капитального строительства отапливаемых помещений.

Для освоения имеющегося туристического потенциала объекта необходимо провести следующие мероприятия:

1. Улучшение транспортной доступности, то есть объект должен стать максимально доступным для посещения - туристы всех категорий должны иметь возможность выбора различных вариантов транспорта. В первую очередь необходимо строительство автомобильной дороги непосредственно до стационара с учётом дополнительных характеристик: наличие автомобильной парковки, оборудованных пешеходных троп, возможности посещения людьми с ограниченными возможностями и др. В настоящее время растет поток самостоятельных автотуристов, которые при условиях улучшенной транспортной доступности стационара смогут стать его посетителями без посредничества турфирм. Также необходимо расширение ассортимента услуг, таких как прокат автомобилей, предоставление местного транспорта для проведения обзорных экскурсий и трансферов до мест размещения.

2. Для активизации экономических инициатив необходимо провести ряд обучающих семинаров для разных категорий местного населения (по организации гостевых домов, производству сувенирной продукции и внедрению стандартов экологического туризма, обучению экскурсоводов). Во многих случаях первым решением, которое геопарки применили для развития местной экономики, стало производство новых продуктов - это не только сувениры, основанные на природном и геологическом наследии (значки, кружки, флаги, футболки, сумки и пр.), но и создание определенного бренда, девиза, логотипа с геологической тематикой. Есть успешные примеры брендовых пищевых продуктов, например, Геококтейл (напитки из минеральной воды) в геопарке Вулкан Айфель (Geopark Vulkaneifel), Германия; хлеб динозавров в геопарке динозавров, (Dino Park), Румыния; трилобитов торт в геопарке Натуртежу (Geopark Naturtejo), Португалия. Туристический интерес могут вызвать декоративные элементы и предметы быта, выполненные в особом стиле. Примером могут служить часы, подсвечники и тому подобные предметы интерьера, выполненные в форме трилобитов (геопарк Натуртежу) [23]. Производство сувениров и другой продукции не только улучшает местную экономику и позволяет представить уникальные местные продукты, но и просвещает туристов, популяризирует геологическое наследие, а также дает возможность получения дополнительного дохода местному населению, что очень актуально для сельских территорий. 
3. Усиление информационного потока на внешних рынках о данном геологическом объекте. Существенным плюсом является то, что местонахождение динозавра остатков Кулиндодромеуса забайкальского и его облик уже хорошо известны в регионе. Так, в 2016 г. изображение Кулиндодромеуса забайкальского было помещено на герб Чернышевского района ${ }^{6}$ (рис. 2).

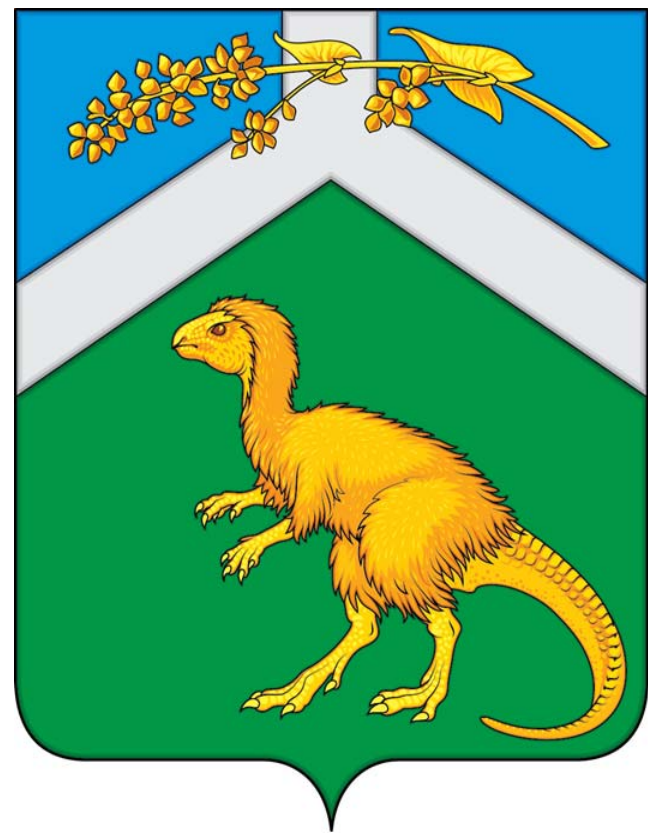

Рис. 2. Герб Чернышевского района Забайкальского края

4. Необходимо создание «Плана управления ООПТ», разработанного с участием местного населения и местной администрации, включая разработку сквозных маршрутов, согласование календаря событий и пр.

\section{Выводы}

Территория учебно-научного стационара «Кулинда», обладающая уникальными объектами и достопримечательностями, может предложить четыре различные формы туристического обслуживания. Физико-географические и социально-экономические условия значительно осложняют возможности развития данной территории без привлечения дополнительных активов.

Для сельских территорий развитие туризма может выступить «точкой роста», однако это возможно только при условии возникновения партнерства между правительством, местным населением и бизнесом. Развитие сопутствующих производств для обслуживания ООПТ поможет стабилизировать социально-экономическую ситуацию в сельском поселении Новоильинское при условии устойчивого спроса на услуги.

Создание учебно-научного стационара «Кулинда» со специфическими задачами, в числе которых: сохранение природных объектов и достопримечательностей, изучение естественных процессов в природе, просвещение и воспитание населения, проведение учебно-научных практик студентов, познавательных экскурсий, значительное повышение уровня научных данных о территории. В конечном итоге создание учебно-научного стационара будет способствовать росту познавательной активности населения.

Автор выражает благодарность сотрудникам ИПРЭК СО РАН д.г.-м.н. Софье Михайловне Синице и младшему научному сотруднику Вере Ивановне Гильфановой за ценные консультации, полученные при подготовке статьи.

Работа выполнена в рамках проекта: № 0386-2017-0008 «Пространственное развитие востока России: проблема обеспечения эколого-экономического баланса в приграничных регионах».

\footnotetext{
${ }^{6}$ Решение Совета муниципального района «Чернышевский район» от 10.02.2016. № 1.
} 


\section{СПИСОК ЛИТЕРАТУРЫ}

1. Пчелинцев О.С. Региональные условия экономического роста // Проблемы прогнозирования. 2004 . № 3. C. 53-70.

2. Концепция развития системы ООПТ регионального значения в Забайкальском крае на период до 2030 года. URL: http://docs.cntd.ru/document/432943433.

3. Агафонов Г.М. Место и роль учебно-научных стационаров в региональной системе ООПТ // Эволюция биосферы и техногенез: сб. тр. всерос. конф., посвящ. 35-летию ИПРЭК СО РАН. Чита, 2016. С. 189-191.

4. Иванов А.Н., Чижова В.П. Охраняемые природные территории: учеб. пособие. М.: Изд-во Моск. ун-та, 2003. $119 \mathrm{c}$.

5. Топ-10 самых важных научных открытий 2014 года по версии Science. URL: https://korrespondent.net/ tech/science/3460367-top-10-samykh-vazhnykh-nauchnykh-otkrytyi-2014-hoda-po-versyy-Science.

6. Godefroit P., Sinitsa S.M., Dhouailly D., Bolotsky Y.L., Sizov A.V., McNamara M.E., Benton M.J., Spagna P. A Jurassic ornithischian dinosaur from Siberia with both feathers and scales // Science. 2014. V. 345. № 6195. P. 451-455. Doi: 10.1126/science.1253351

7. Синица С.М., Вильмова Е.С., Юргенсон Г.А., Решетова С.А., Филенко Р.А. Геологические памятники Забайкалья. Новосибирск: Наука, 2014. 311 с.

8. Синица С.М., Вильмова Е.С. Палеоэкологические и тафономические особенности биоты местонахождения юрских динозавров (Кулинда, Оловская впадина, Забайкалье) // Уч. зап. ЗабГУ. 2016. Т. 1. № 1. С. $149-157$.

9. Синица С.М. Юрские динозавры Забайкалья и перспективы их поисков в Монголии // Палеонт. журнал. 2016. Vol. 50. № 12. С.1401-1412.

10. Зеленая Книга Сибири: Редкие и нуждающиеся в охране растительные сообщества / под ред. В.И. Валуцкого, Н.Б. Ермакова, А.Ю. Королюка, Т.В. Мальцевой, В.П. Седельникова, Г.С. Тарана, М.Ю. Телятникова. Новосибирск: Наука. Сибирская издательская фирма РАН, 1996. 396 с.

11. Михеев В.С. Сибирские географические стационары // Географическое изучение Азиатской России. Иркутск, 1997. С. 24-33.

12. Dowling R. Geotourism's Global Growth // Geoheritage. 2011. Vol. 3. P. 1-13.

13. Рубан Д.А. Академические формы геологического туризма // Вестн. Алтайской академии экономики и права. 2015. №4 (42). С. 110-114.

14. Ермакова Ж.А. Научный туризм в России / под ред. Ж. А. Ермакова, Ю. Е. Холодилина. Екатеринбург: Ин-т экономики УрО РАН, 2014. 197 с.

15. Синица С.М., Мясников А.В., Вильмова Е.С. Научный туризм в Оловской впадине Забайкалья // Вестн. Заб. гос. ун-та. 2014. №9 (112). С. 37-48.

16. Помазкова Н.В., Фалейчик Л.М. Оценка эколого-хозяйственного баланса территории Забайкальского края // Вестн. Воронежского гос. ун-та. Серия: География. Геоэкология. 2018. №2. С. 5-15.

17. Комплексная программа социально-экономического развития муниципального района «Чернышевский район» Забайкальского края на период 2011-2020 гг. Чернышевск, 2011. 328 c. URL: http://passport.zabinvestportal.ru/downloads/districts/programma_chernishevski_rayon.pdf.

18. Бутько Е.В. Особо охраняемые природные территории регионального значения в Забайкальском крае: современное состояние и перспективы развития // Шелковый путь. Транссиб. Маршруты сопряжения: экономика, экология: сб. мат-лов Междунар. науч-практ. конф. и Симпозиума, посвящ. 100-летию заповедного дела и Году экологии в России. Чита: ИПРЭК СО РАН, 2017. С. 25-29.

19. Dowling R. Global Geotourism - an emerging form of sustainable tourism // Czech Journal of Tourism, 2013. 2(2). P. 59-79.

20. Chen A., Lu Y., Ng YCY The principles of geotourism. Beijing: Science Press, 2015. 264 p.

21. Alberto C., Luis A. Palaeontological heritage as a resource for promoting geotourism in the rural setting: el castellar (Teruel, Spain) // Geoheritage, 2018. №. 10. P. 405-414. DOI 10.1007/s12371-017-0248-x

22. Практично, выгодно, безопасно. Пособие для начинающих по развитию экологически безопасного туризма в особо охраняемых природных территориях, 2015. URL: https:/greatbaikaltrail.org/sites/default/files/ posobie_dlya_nachinayushchih_dlya_razvitiya_ekologicheski_bezopasnogo_turizma_v_oopt.pdf.

23. Farsani N.T., Coelho C., Costa C. Geotourism and Geoparks as Novel Strategies for socio-economic Development in Rural Areas // Int. J. Tourism Res. 2011. №13. P. 68-81 DOI: 10.1002/jtr.800.

Поступила в редакцию 10.01.2019

Помазкова Надежда Викторовна, кандидат географических наук, научный сотрудник

Институт природных ресурсов, экологии и криологии СО РАН

672014, Россия, Чита, ул. Недорезова, 16а

E-mail: naste2@yandex.ru 


\section{N.V. Pomazkova \\ CREATION OF "KULINDA" SCIENTIFIC AND TRAINING STATION AND PERSPECTIVES OF INVOLVEMENT OF THE REGIONAL PROTECTED NATURAL AREA INTO SOCIAL AND ECONOMIC DEVELOPMENT OF THE REGION}

DOI: $10.35634 / 2412-9518-2019-29-2-290-299$

One of the main principles of "green economy" is the organization of business activity in such a way as to enhance welfare of people and provide for social equity while considerably decreasing risks of the environmental degradation. The purpose of the article is to study possibilities and conditions of involvement of the regional protected natural area being created into social and economic development. "Kulinda" scientific and training station in the Chernyshevsky District of the Trans-Baikal Territory is being created for preservation and study of the unique location where Kulindadromeus zabaikalicus dinosaur fossils have been found. The station is referred to the new category of regional specially protected natural areas. The performed studies have confirmed the conservation value of the territory and necessity of specially protected natural area creation in the Chernyshevsky District of the Trans-Baikal Territory. The nearest rural settlement (village of Novoilinsk) is an area with an unfavorable socio-economic situation: low standard of living, unemployment, and annual outflow of population. Development of tourism on the basis of natural resources and areas of interest of the scientific and training station is viewed as a possibility to involve population of villages being abandoned into the economic activity. The article analyzes available opportunities and perspective directions of tourism for the object: geological (geotourism), academical (scientific), educational, agricultural (agrotourism), and ecological tourism. In addition, the article considers negative factors hindering the development of rural areas and the scientific and training station: lack of financing, poor transport accessibility, imperfection of service infrastructure, and seasonality of the scientific and training station activity. The author makes a conclusion that development of tourism in specially protected natural areas can become a growing point for economy of rural regions through the development of associated service industries and can contribute to the growth of educational activity of the population.

Keywords: scientific and training station, specially protected areas, Kulinda, Kulindadromeus zabaikalicus, tourism, welfare of people.

\section{REFERENCES}

1. Pchelincev O.S. [Regional conditions for economic development] in Problemy prognozirovaniya, 2004, no. 3, pp. 53-70 (in Russ).

2. Koncepciya razvitiya sistemy OOPT regional'nogo znacheniya v Zabajkalskom krae na period do 2030 goda, [The concept of development of regional protected areas in the TRANS-Baikal territory for the period up to 2030], Available: http://docs.cntd.ru/document/432943433 (accessed 19.12.2018) (in Russ).

3. Agafonov G.M. [Place and role of educational and scientific hospitals in the regional system of protected areas], in Sborn. nauch. tr. «Biosphere evolution and technogenesis», Chita, 2016, pp. 189-191(in Russ).

4. Ivanov A.N. and Chizhova V.P. Ohranyaemye prirodnye territorii [Protected natural territory]. Moscow: Moscow Gos.Univ., 2003, 119 p. (in Russ).

5. Top-10 samyh vazhnyh nauchnyh otkrytij 2014 goda po versii Science. Available: https://korrespondent.net/tech/ science/3460367-top-10-samykh-vazhnykh-nauchnykh-otkrytyi-2014-hoda-po-versyy-Science (accessed 12.12.2018) (in Russ).

6. Godefroit P., Sinitsa S. M., Dhouailly D., Bolotsky Y.L., Sizov A. V., McNamara M. E., Benton M. J., Spagna P. A Jurassic ornithischian dinosaur from Siberia with both feathers and scales in Science, 2014, vol. 345. no. 6195. pp. 451-455. Doi: 10.1126/science.1253351

7. Sinica S.M., Vilmova E.S., Yurgenson G.A., Reshetova S.A. and Filenko R.A. Geologicheskie pamyatniki Zabajkalya [Geological monuments of Transbaikalia], Novosibirsk: Nauka, 2014, 311 p. (in Russ).

8. Sinitsa S.M., Vilmova E.S. [Paleoecological and taphonomically features of the biota of the location of the Jurassic dinosaurs (Kulinda, Olowska depression, Transbaikalia)] in Uch. zapiski ZabGU, 2016. vol. 1, no. 1. pp.149-157 (in Russ).

9. Sinitsa S.M. [Jurassic dinosaurs of Transbaikalia and prospects of searching for them in Mongolia] in Paleont. zhurnal [Paleontological journal], 2016.Vol. 50, no. 12. pp.1401-1412. Doi: 10.1134/S0031030116120170

10. Zelenaya Kniga Sibiri: Redkie i nuzhdayushchiesya v ohrane rastite'nye soobshchestva [Green Book of Siberia: Rare and in need of protection plant communities], Valutsky V.I., Ermakov N.B., Korolyuk A.Yu., Maltseva T.V., Sedelnikov V.P., Taran G.S. and Telyatnikov M.Yu. (ed) Novosibirsk: Nauka. Sibirskaya izdatelskaya firma RAN, 1996, 396 p. (in Russ).

11. Miheev V.S. [Siberian geographical scientific station] in Geograficheskoe izuchenie Aziatskoj Rossii. Irkutsk, 1997, pp. 24-33(in Russ).

12. Dowling R. Geotourism's Global Growth in Geoheritage, 2011, vol. 3, pp. 1-13. 
13. Ruban D.A. [Academic forms of geological tourism] in Vestn. Alt. akad. ekonomiki i prava, 2015, no. 4 (42), pp. 110-114(in Russ).

14. Nauchnyj turizm v Rossii [Scientific tourism in Russia] Ermakov Zh.A. and Holodilin Yu.E. (ed), Yekaterinburg: Inst. ekonomiki UrO RAN, 2014, 197 p. (in Russ).

15. Sinica S.M., Myasnikov A.V., Vilmova E.S. [Scientific Tourism in Olov Depression of Transbaikalie] in Vestn. Zab. Gos. Univ., 2014, no 9 (112), pp. 37-48 (in Russ).

16. Pomazkova N.V. Falejchik L.M. [Assessment of ecological and economic balance of the Transbaikal territory] in Vestn.Voronezh. Gos. Univ.Ser. Geogr. Geoekol, 2018, no.2, pp.5-15(in Russ).

17. Kompleksnaya programma social'no-ekonomicheskogo razvitiya municipal'nogo rajona "Chernyshevskij rajon» Zabajkal'skogo kraya na period 2011-2020 gg .Sajt investicionnyj portal Zabajkalskogo kraya. [Comprehensive program of socio-economic development of the municipal district "Chernyshevsky district" of the Ttansbaikal territory for the period 2011-2020gg] Available: http://passport.zab-investportal.ru/downloads/districts/programma chernishevski_rayon.pdf (accessed 12.12.2018) (in Russ).

18. Butko E.V. [Protected natural areas of regional importance in the Ttansbaikal territory: current state and prospects of development] in Mater.mazhd.nauch.konf. «Shelkovyj put. Transsib. Marshruty sopryazheniya: ekonomika, ekologiya», Chita,BNZ, 2018, pp. 25-29(in Russ).

19. Dowling, R. Global Geotourism - an emerging form of sustainable tourism, in Czech Journal of Tourism, 2013, no. 2(2). pp.59-79

20. Chen A, Lu Y and Ng YCY The principles of geotourism. Beijing: Science Press, 2015, 264 p.

21. Alberto C., Luis A. Palaeontological heritage as a resource for promoting geotourism in the rural setting: el castellar (Teruel, Spain) in Geoheritage, 2018, no. 10. pp. 405-414 DOI 10.1007/s12371-017-0248-x

22. Praktichno, vygodno, bezopasno. Posobie dlya nachinayushchih po razvitiyu ekologicheski bezopasnogo turizma $v$ osobo ohranyaemyh prirodnyh territoriyah [Practical, profitable, safe. Guide for beginners on the development of environmentally safe tourism in protected areas] Available: https://greatbaikaltrail.org/sites/default/files/posobie_dlya nachinayushchih_dlya_razvitiya_ekologicheski_bezopasnogo_turizma_v_oopt.pdf (accessed 20.12.2018) (in Russ).

23. Farsani N.T., Coelho C. and Costa C. Geotourism and Geoparks as Novel Strategies for socio-economic Development in Rural Areas in Int. J. Tourism Res, 2011, no. 13, pp. 68-81 DOI: 10.1002/jtr.800

Received 10.01.2019

Pomazkova N.V., Candidate of Geography, researcher

Institute of Natural Resources, Ecology and Cryology,

Russian Academy of Sciences, Siberian Branch (INREC SB RAS)

Nedorezova st., 16a, Chita, Russia, 672014

E-mail: naste2@yandex.ru 